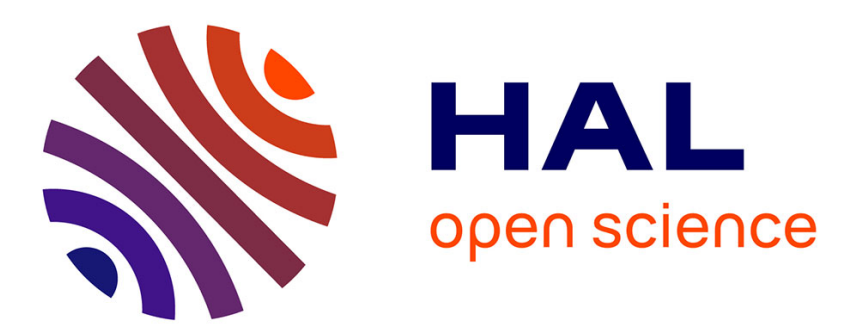

\title{
The key role of highly dispersed rhodium in the chemistry of hydrogen-ceria systems
}

S. Bernal, J.J. Calvino, G.A. Cifredo, J.M. Rodriguez-Izquierdo, V. Perrichon, A. Laachir

\section{- To cite this version:}

S. Bernal, J.J. Calvino, G.A. Cifredo, J.M. Rodriguez-Izquierdo, V. Perrichon, et al.. The key role of highly dispersed rhodium in the chemistry of hydrogen-ceria systems. Journal of the Chemical Society, Chemical Communications, 1992, pp.460-462. 10.1039/C39920000460 . hal-00006220

\section{HAL Id: hal-00006220 \\ https://hal.science/hal-00006220}

Submitted on 21 May 2021

HAL is a multi-disciplinary open access archive for the deposit and dissemination of scientific research documents, whether they are published or not. The documents may come from teaching and research institutions in France or abroad, or from public or private research centers.
L'archive ouverte pluridisciplinaire HAL, est destinée au dépôt et à la diffusion de documents scientifiques de niveau recherche, publiés ou non, émanant des établissements d'enseignement et de recherche français ou étrangers, des laboratoires publics ou privés.

\section{(c)(1)}

Distributed under a Creative Commons Attribution| 4.0 International License 


\title{
The Key Role of Highly Dispersed Rhodium in the Chemistry of Hydrogen-Ceria Systems
}

\author{
S. Bernal,* a J. J. Calvino, a G. A. Cifredo, a J. M. Rodríguez-lzquierdo, a V. Perrichon b and A. Laachir \\ a Departamento de Química Inorgánica, Facultad de Ciencias, Universidad Cádiz, Puerto Real, 11510 Cádiz, \\ Spain \\ b Institut de Recherches sur la Catalyse, 2 Avenue Albert Einstein, 69626 Villeurbanne Cedex, France \\ In the presence of rhodium, the $\mathrm{H}_{2}-\mathrm{CeO}_{2}$ interaction is to a large extent reversible, simple evacuation of the \\ reduced sample has been demonstrated to promote reoxidation of the support; this explains some puzzling \\ effects of the reduction/evacuation treatments on the actual oxidation state of ceria in $\mathrm{Rh}^{-\mathrm{CeO}} \mathrm{O}_{2} \mathrm{catalysts}$
}

In the last few years, many research groups have concentrated their efforts in the study of the redox surface chemistry of ceria, an essential piece of knowledge in understanding some of its most interesting catalytic properties, i.e. its oxygen storage capacity, ${ }^{1}$ its singular chemisorptive properties against $\mathrm{H}_{2}, 2-5$ or the precise nature of the strong metal-support interaction phenomena suggested to occur over a number of metal- $\mathrm{CeO}_{2}$ systems.6.10 Many important questions remain unanswered as yet. In particular, the role played by highly dispersed metals has not been extensively investigated.

The catalyst, with $2.9 \%$ metal loading by mass, was prepared by incipient wetness impregnation from an aqueous solution of $\mathrm{Rh}\left(\mathrm{NO}_{3}\right)_{3}$. After the impregnation step, it was dried in air, at $383 \mathrm{~K}$, for $10 \mathrm{~h}$, and then stored until it was reduced in situ with hydrogen, at $623 \mathrm{~K}$, for $1 \mathrm{~h}$. The cerium dioxide was a high surface area $\left(135 \mathrm{~m}^{2} \mathrm{~g}^{-1}\right)$ sample. The 

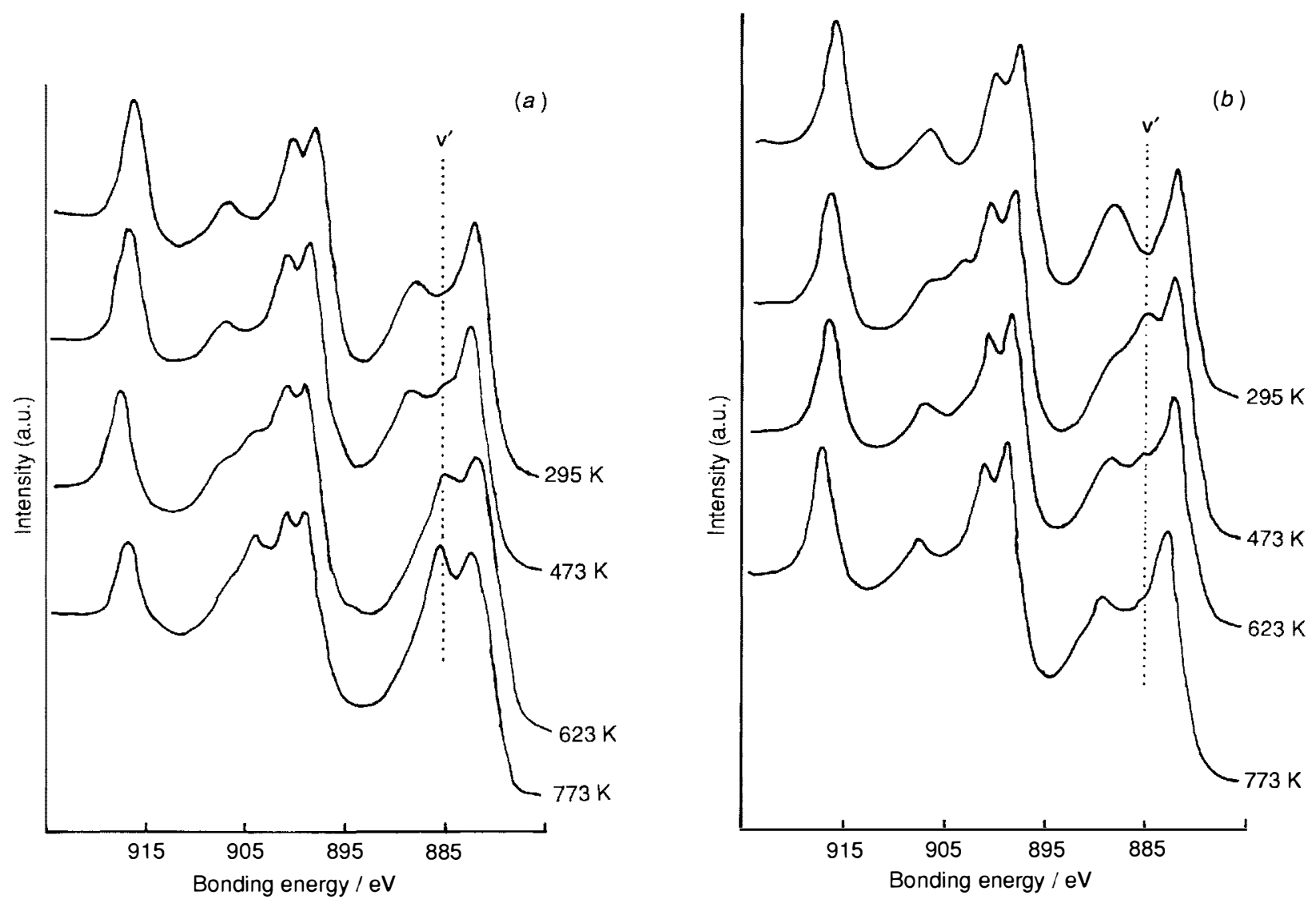

Fig. 1 XPS spectra of the $\mathrm{Ce} 3 \mathrm{~d}$ transitions in $(a)$ bare $\mathrm{CeO}_{2}$ and $(b) \mathrm{Rh}-\mathrm{CeO}_{2}$ system submitted to the following conditions: (i) evacuation at $295 \mathrm{~K}$; (ii) heating under $\mathrm{H}_{2}\left(P_{\mathrm{H}_{2}}=760\right.$ Torr) and further evacuation at $473 \mathrm{~K}$; (iii) similar conditions to (ii), temp. $623 \mathrm{~K} ;($ iv) similar conditions to (ii) and (iii), temp. $773 \mathrm{~K}$

Brunauer-Emmett-Teller (BET) surface area was not significantly modified by either the impregnation or the reduction treatments. High resolution electron microscopy images showed that the rhodium dispersion was very high, with metal crystallites not larger than $1.5 \mathrm{~nm}$.

Experimental details about the Faraday microbalance which was used and the way of estimating the percentage of $\mathrm{Ce}^{\mathrm{IV}}$ reduced after each of the treatments are given elsewhere. 3.11

A precursor/support sample, the mass of which was 128.5 $\mathrm{mg}$, was submitted to the successive series of treatments indicated in Table 1. In accordance with this Table, the initial hydrogen treatment at $623 \mathrm{~K}$ leads to the reduction of ceria to an extent, $26.1 \%$, quite close to that reported ${ }^{3}$ for the reduction of a bare high surface area $\left(115 \mathrm{~m}^{2} \mathrm{~g}^{-1}\right)$ oxide sample. The effect of the evacuation treatment $\left(P<10^{-8}\right.$ Torr; 1 Torr $=133.322 \mathrm{~Pa})$ at the reduction temperature, however, is completely different for $\mathrm{CeO}_{2}$ and $\mathrm{Rh}-\mathrm{CeO}_{2}$. In the first case, for ceria only, the reduction level remains unaltered, whereas, over $\mathrm{Rh}-\mathrm{CeO}_{2}$, support reoxidation occurs to a large extent.

The results reported in Table 1 demonstrate that at room temperature, the catalyst takes up large amounts of hydrogen, apparent H/Rh: 5.7, in good agreement with the results obtained from volumetric measurements. For ceria only no significant hydrogen adsorption takes place below $473 \mathrm{~K} \cdot .^{3.4}$ The spill over observed at $295 \mathrm{~K}$ on our $\mathrm{Rh}-\mathrm{CeO}_{2}$ catalyst implies the reduction of ceria to a similar extent to that reached after the treatment with hydrogen at $623 \mathrm{~K}$. Data included in Table 1 also show that we can arrive at a cyclic reproducible behaviour for the $\mathrm{H}_{2}-\left(\mathrm{Rh}-\mathrm{CeO}_{2}\right)$ system, thus indicating that, in the presence of highly dispersed rhodium, hydrogen chemisorption on ceria is to a large extent reversible. Furthermore, upon raising the evacuation temperature up to $773 \mathrm{~K}$, some further reoxidation of ceria occurs, the final reduction level reached by the support being similar to that of the starting, untreated with hydrogen, sample.

The results presented here suggest that the actual state of ceria submitted to a reduction treatment with hydrogen depends critically on the presence of the metal. For ceria only, irreversible reduction of the oxide, leading to the elimination of $\mathrm{H}_{2} \mathrm{O}$, and therefore to the creation of oxygen vacancies, takes place to a much larger extent. This can be important when discussing the likely occurrence and actual nature of metal-support interaction in metal- $\mathrm{CeO}_{2}$ catalysts. It can also be deduced from our results that the evacuation conditions, rather than the reduction treatment can constitute the key factor in determining the reduction level reached by ceria in rhodium containing phases.

Fig. 1 shows $\mathrm{Ce}(3 \mathbf{d}) \mathrm{X}$-ray photoelectron spectroscopy (XPS) spectra corresponding to our $\mathrm{CeO}_{2}$ and $\mathrm{Rh}-\mathrm{CeO}_{2}$ samples, untreated as well as reduced with $\mathrm{H}_{2}$ at 473,623 and $773 \mathrm{~K}$. Upon analysing these two series of spectra, more specifically the variation throughout them of the relative intensity of the so-called $\mathrm{v}^{\prime}$ peak, considered to be as a characteristic feature of $\mathrm{Ce}^{111}$ ions, ${ }^{12}$ some conclusions can be drawn. In contrast with that found for ceria only, for which the reduction degree increases as the reduction temperature does ${ }^{3}$ for $\mathrm{Rh}-\mathrm{CeO}_{2}$ the highest reduction level is reached at $473 \mathrm{~K}$, becoming lower at higher reduction temperatures. $\mathrm{Rh}(3 \mathrm{~d})$ XPS spectra, on the other hand, show that the three reduction treatments lead to $\mathrm{Rh}^{0}$. This, in principle, puzzling result can reasonably be interpreted as owing to reoxidation of ceria occurring during the evacuation following the hydrogen treatment of $\mathrm{Rh}-\mathrm{CeO}_{2}$ samples. Also worth of noting is that after reduction at $473 \mathrm{~K}$, the rhodium containing sample becomes more deeply reduced than the bare support. The opposite is true for higher reduction temperatures. This is very 
Table 1 Magnetic balance study of the process undergone by a sample of $\mathrm{Rh}\left(\mathrm{NO}_{3}\right)_{3}-\mathrm{CeO}_{2}$ submitted to the series of treatments indicated below

\begin{tabular}{|c|c|c|c|c|}
\hline Treatment & $\Delta m_{t}^{\prime \prime}$ & $\chi^{b}$ & $\Delta n_{\mathrm{H}_{2}}{ }^{c}$ & $\% \mathrm{Ce}^{3+}$ \\
\hline Evacuation & & -0.18 & & 0 \\
\hline $\begin{array}{l}T: 623 \mathrm{~K}: t: 1 \mathrm{~h}^{d} \\
\text { Evacuation }\end{array}$ & -59.7 & +1.42 & +0.74 & 26.1 \\
\hline $\begin{array}{l}T: 623 \mathrm{~K} ; t: 2 \mathrm{~h} \\
\text { Cooling to }\end{array}$ & -2.25 & +0.40 & -0.47 & 9.5 \\
\hline$T: 295 \mathrm{~K}$ & - & +0.80 & - & 9.2 \\
\hline $\begin{array}{l}T: 295 \mathrm{~K}: t: 27 \mathrm{~h}^{d} \\
\text { Evacuation }\end{array}$ & +1.61 & +2.28 & +0.41 & 23.2 \\
\hline $\begin{array}{l}T: 295 \mathrm{~K}: t: 1 \mathrm{~h} \\
\text { Evacuation }\end{array}$ & -0.19 & +2.14 & -0.04 & 21.8 \\
\hline $\begin{array}{l}T: 473 \mathrm{~K}: t: 1 \mathrm{~h} \\
\text { Evacuation }\end{array}$ & -0.89 & +0.80 & -0.26 & 13.0 \\
\hline $\begin{array}{l}T: 623 \mathrm{~K} ; t: 1 \mathrm{~h} \\
\text { Cooling to }\end{array}$ & -0.49 & +0.40 & -0.10 & 9.5 \\
\hline$T: 295 \mathrm{~K}$ & - & +0.60 & - & 7.4 \\
\hline $\begin{array}{l}T: 295 \mathrm{~K}: t: 22 \mathrm{~h}^{d} \\
\text { Evacuation }\end{array}$ & +1.36 & +2.24 & +0.45 & 22.8 \\
\hline $\begin{array}{l}T: 295 \mathrm{~K}: t: 1 \mathrm{~h} \\
\text { Evacuation }\end{array}$ & -0.24 & +2.08 & -0.04 & 21.0 \\
\hline $\begin{array}{l}T: 473 \mathrm{~K}: t: 1 \mathrm{~h} \\
\text { Evacuation }\end{array}$ & -0.83 & +0.74 & -0.25 & 12.3 \\
\hline $\begin{array}{l}T: 623 \mathrm{~K}: t: 1 \mathrm{~h} \\
\text { Evacuation }\end{array}$ & -0.45 & +0.35 & -0.10 & 8.7 \\
\hline $\begin{array}{l}T: 773 \mathrm{~K}: t: 1 \mathrm{~h} \\
\text { Cooling to }\end{array}$ & -1.17 & +0.14 & -0.05 & 6.4 \\
\hline$T: 295 \mathrm{~K}$ & -- & +0.36 & - & 5.1 \\
\hline
\end{tabular}

"Variation of the total mass of the sample $\left(\mathrm{mg} \mathrm{g}^{-1}\right)$ associated to the corresponding treatment. $"$ Magnetic susceptibility of the sample in electromagnetic unit $\mathrm{g}^{-1} \times 10^{6}$ measured at the temperature of the experiment. "Estimate (in $\mathrm{mmol} \mathrm{g}^{-1}$ of catalyst) of the amount of hydrogen associated in the variation in the concentration of $\mathrm{Ce}^{\mathrm{III}}$ ions as determined from magnetic measurements. ${ }^{d} \mathrm{H}_{2}(P=300$ Torr $)$.

consistent with our observations ${ }^{3.4}$ in the sense that the hydrogen interaction with pure cerium dioxide just starts to be observed at $473 \mathrm{~K}$.
Our results can also be very helpful to interpret the temperature programmed desorption- $\mathrm{H}_{2}$ diagrams as well as the conventional hydrogen volumetric chemisorption studies carried out on $\mathrm{Rh}-\mathrm{CeO}_{2}$ catalysts. In particular would be stressed the occurrence of hydrogen desorption from the support below $473 \mathrm{~K}$, even at $295 \mathrm{~K}$. Obviously, this obliged us to be cautious in assigning the hydrogen forms desorbed in the low temperature region, i.e. $295-473 \mathrm{~K}$, to species chemisorbed on the metal, or even to the so-called reversible forms.

This work has received financial support from the CICYT, Project: PB87-0961. One of us (S. B.) acknowledges the Grant received from the 'Programa Mercurio'. The ceria sample used here was kindly donated by Rhône-Poulenc Minerale Fine.

\section{References}

1 H. C. Yao and Y. F. Yao, J. Catal., 1984, 86, 254.

2 J. L. G. Fierro, J. Soria, J. Sanz and J. M. Rojo, J. Solid State Chem., 1987, 66, 154

3 A. Laachir, V. Perrichon, A. Badri, J. Lamotte, E. Catherine, J. C. Lavalley, J. El Fallah, L. Hilaire, F. Le Normand, E. Quéméré, G. N. Sauvion and O. Touret. J. Chem. Soc., Faradav Trans., 1991, 87, 1601.

4 S. Bernal, J. J. Calvino, G. A. Cifredo, J. M. RodríguezIzquierdo, V. Perrichon and A. Laachir, J. Catal., in the press

5 P. J. Levy and M. Primet, Appl. Catal., 1991, 70, 263.

6 J. Cunningham, S. O’Brien, J. Sanz, J. M. Rojo, J. Soria and J. L. G. Fierro, J. Mol. Catal., 1990, 57, 269.

7 J. Barrault, A. Alouche, V. Paul-Boncour, L. Hilaire and A. Percheron-Guegan, Appl. Catal., 1990, 57, 379.

8 M. Guenin, P. N. Da Silva and R. Frety, Appl. Catal., 1986, 27, 313.

9 P. Meriaudeau, J. F. Dutel, M. Dufaux and C. Naccache, Stud. Surf. Sci. Catal. 1982, 11.95.

10 M. G. Sánchez and J. L. Gázquez, J. Catal., 1987. 104, 120.

11 V. Perrichon, J. P. Candy and P. Fouilloux, in Progress in Vacuum Microbalance Techniques, eds M. Eyraud and M. Escoubes, Heyden, London, 1975, vol. 5, p. 18.

12 F. Le Normand, L. Hilaire, K. Kili, G. Krill and G. Maire. J. Phys. Chem., 1988, 92, 2561. 